\title{
BIOMASS PRODUCTION AND NODULATION OF GREEN MANURE LEGUMES IN COCONUT BASINS IN LATERITE SOIL AND THEIR INFLUENCE ON SOIL FERTILITY
}

\author{
G.V. Thomas ${ }^{1}$ and M.V. Shantaram**
}

\begin{abstract}
Biomass production, nitrogen yield and nodulation by ten species of green manure legumes were compared in coconut basins in a root (wilt) affected garden under laterite soil type. Pueraria phaseoloides, Calopogonium mucunoides and Mimosa invisa were superior to others and yielded 28.45, 27.21 and $24.97 \mathrm{~kg}$ of biomass and 196.2, 186.5 and $187.6 \mathrm{~g}$ of nitrogen basin- ${ }^{1}$, respectively. The performance of Mucuna bracteata Crotalaria juncea and Macroptilium atropurpureum were also better with a biomass production of $16-21 \mathrm{Kg}$ basin- ${ }^{1}$ and nitrogen yield of 108-140 g basin- ${ }^{1}$. Incorporation of green manures obtained from $C$. mucunoides, $P$. phaseoloides and $M$. invisa resulted in an increase in the level of major nutrients viz. N, P and $\mathrm{K}$ in coconut basin soils. Mineralisation of carbon was also greater in green manured coconut basin soils when compared to that in control. The increase in nutrient levels and mineralisation of carbon was more in treated basins at 30 days of incorporation of green manures when compared to the levels before the harvest of the legumes and at 60 days of incorporation.
\end{abstract}

\section{INTRODUCTION}

Though organic manuring is proved vastiy beneficial in coconut cultivation, it is seldom practised by the farmers clue to the nonavailability of organic manures. The basin area of $1.8 \mathrm{~m}$ radius around the bole of the coconut palm is generally not utilized for any other purpose. The feasibility of utilizing coconut basins for growing green manure legumes in coastal sandy tracts and the effect of green manuring on soil microbial parameters have been previously reported (Thomas and Shantaram, 1984; Thomas, 1987). The biomass production and nitrogen contribution by green manure legumes and their influence on soil fertility parameters vary with soil type and climatic factors. This study is aimed at identifying suitable green manure legumes for basin management of coconut in laterite soils and to evaluate the effect of basin management on nutrient status and mineralisation of carbon in coconut basin soils.

\section{MATERIALS AND METHODS}

\section{Establishment of green manure legumes}

A field experiment was conducted to screen ten species of green manure legumes in coconut basin in a farmer's garden at Vallikunnam (Alleppey dt., Kerala) in a heavily root (wilt) affected tract. The garden comprised of 25 to 30 year-old bearing coconut palms of 'West Coast Tall' Cultivar. The basins around the palms were opened to a radius of $1.8 \mathrm{~m}$ and sown with $25 \mathrm{~g}$ seeds of the green manure legumes with the onset of monsoon in June as described earlier (Thomas and Shantaram, 1984). Each green manure legume was grown in basins of eight coconut palms each and the experiment was conducted for two years. Calopogonium mucunoides Desv., Macrotylorna axillaire (E. Mey) Verdc, Mimosa invisa Mert., Macroptilium atropurpureum (D.C.) Urb., Pueraria phaseoloides (Roxb.) Benth, Centroserna pubescen Benth., Leucaena leucocephala (Lam.) de Wit

${ }^{1}$ Central Plantation Crops Research Institute, and Department of Soil Science and Agricultural Chemistry, APAU, India, respectively. 
and Sesbania aegiptica. Poir were the legumes tested in the first year. The last two legumes did not establish well in basins and they were replaced by Mucuna bracteata D.C. and Crotalaria juncea Linn. in second year. L. leucocephala seeds were scarified with hot water to facilitate germination. Since $M$. breatata does not seed under prevailing environmental conditions, rooted cuttings of the legurne were planted. The plant tops were harvested after 120 days and the green matter yield per basin was recorded. The data on nodule number and nodule dry weight were determined by uprooting five plants from each basin. Nitrogen content of shoots was determined by microkjeldahl method after drying the samples at $70^{\circ} \mathrm{C}$. The harvested plant tops were incorporated in respective coconut basins. All the palms were maintained with the recommended package of practices for coconut. One-third of the fertilizers were applied before sowing of the legumes and the remaining two-third with the incorporation of the legumes.

The green manure legumes viz. Pueraria phaseoloides, Mimosa invisa and Calopogonium mucunoides which yielded maximum green matter and nitrogen were selected for further studies. Soil samples were collected from basins under the treatment with the above three greenmanure crops and control at $0-25 \mathrm{~cm}$ depth one meter away from the base of the palm.

Soil samples collected at different intervals viz. maximum vegetative stage of green manure crops and at 30 and 60 days of incorporation of green manures were analysed to estimate the levels of major nutrients viz. total nitrogen by Kjeldahl method (Bremner, 1965), available phosphorus by the method of Bray and Kurtz (1945) and potassium by the method of Stanford and English (1949).

\section{Mineralisation of carbon}

The rate of mineralisation of carbon was determined by following the procedure of Pramer and Schmidt (1964). $50 \mathrm{~g}$ portions of soil samples were incubated at $60 \%$ water holding capacity in closed containers and test tubes were introduced in incubation containers with alkali (IN NaOH) and the amount of $\mathrm{CO}_{2}$ absorbed in the alkali was determined by titration with acid (IN HCL) at the end of $1,2,3,4,6,8,10$ and 12 weeks of incubation.

\section{RESULTS}

\section{Biomass and nitrogen yield}

The data presented in Table 1 show that green manure legumes differed in biomass production and N2 accumulation in coconut basins in the laterite soil type. Pueraria phaseoloides, Calopogonium muctmoides and Mimosa invisa were superior to others in producing large quantities of biomass and accumulating nitrogen in coconut basins. Other legumes such as Mucuna bracteata, Crotalaria juncea and Macroptilium atropurpureum were also better whereas legumes such as Macrotylom axillaire, Centrosema pubescens, Leucaena leucocephal and Sesbania aegiptica did not establish well in the basins. Maximum biomass vield was $28.45 \mathrm{~kg}$ basin- ${ }^{1}$ in $P$. phaseoloides followed by $27.21 \mathrm{~kg}$ in G. muctmoides and $24.97 \mathrm{~kg}$ by M. invisa. The nitrogen yield from the shoot portion of green manures exhibited similar trend as biomass yield. M. invisa yielded a maximum of $197.6 \mathrm{~g} \mathrm{~N}$ basin- $^{1}$ followed by $196.2 \mathrm{~g}$ by $P$. phaseoloides and $186.5 \mathrm{~g}$ by $\mathrm{C}$. muctmoides. The nitrogen yield was also better with M. bracteata $(140.1 \mathrm{~g})$, M. atropurpureum (1 $16.6 \mathrm{~g}$ ) and Cjuncea (108.5 g). Other legumes yielded less than $50 \mathrm{~g} \mathrm{~N}$ basin- ${ }^{1}$,

\section{Nodulation}

All the tested legumes were nodulated by native rhizobia, but the nodulation pattern varied in different legumes. M. invisa, P. phaseoloides and C. mucunoides showed superiority in nodulation also with respect to both nodule number and nodule biomass, S. aegiptica was well 
nodulated by native rhizobia, but it failed to produce significant quantities of biomass. On the other hand, $M$. atropurpureum was better in biomass production but was poorly nodulated by native rhizobia. C. pubescens, M. axillaire and L. leucocephala showed poor nodulation in laterite soil also.

\section{Nutrient status}

The data on the changes in the level of major nutrients viz. N, P and $\mathrm{K}$ in coconut basins due to cultivation and incorporation of green manure legumes are presented in Fig. 1. Analysis of coconut basin soil samples collected at maximurn vegetative stage of green manures did not show any reduction in the levels of $\mathrm{N}$ and $\mathrm{P}$ but there was reduction in the level of $\mathrm{K}$ when compared to levels in control. The nutrients level increased considerably in green manured basins at 30 days of incorporation. But the difference between green manured and control basins was less at 60 days of incorporation. Increase in nutrient levels was observed due to the incorporation of $P$. phaseoloides, $M$. invisa and $C$. mucunoides but the difference due to the incorporation of the three legumes was not marked.

\section{Mineralisation of carbon}

Mineralisation of carbon which is an index of soil microbial activity was greater in green manured basins when compared to that in control both at maximurn vegetative stage of green manures and at 30 days of incorporation (Fig. 2). However, there was little difference between control and green manured basins at 60 days of incorporation. Net carbon mineralisation did not show much variation under different legurne treatments. Studies on the rate of mineralisation at different incubation periods showed higher mineralisation rate in green manured basins when compared to that in control at all the incubation periods (Fig. 3). The general pattern of mineralisation was the same for all the plant residues incorporated. Rapid mineralisation occurred upto the fourth week of incubation. The difference in the rate of mineralisation between green manured and control basins become more marked with the increase in incubation period.

\section{DISCUSSION}

Majority of coconut gardens in Kerala are located in the laterite soil type. The present study showed that the legumes such as. C. mucunoides, $P$. phaseoloides and $M$. invisa can be used for basin management of coconut in the laterite soil type. The biomass production and $\mathrm{N}_{2}$ yield of the three promising legumes were much higher in this soil type as compared to the yields obtained in coastal sandy soils. The biomass yields of C. mucupoides, P. phaseoloides and M. invisa obtained in coastal sandy soil were $14.71,19.43$ and $17.00 \mathrm{~kg}$ basin- ${ }^{1}$ (Thomas and Shantaram, 1984).

Pueraria and Calopogonium have been reported as efficient cover crops in the major coconut growing countries such as Philippines (Cabato, 1970) and Inclonesia (Redshaw, 1982) for growing in the interspaces in coconut gardens. The present study showed the better utility of these legumes as green manure crops which could add considerable amount of green matter and $\mathrm{N}$, in a short period of time in coconut basins. Many of these legumes except Muсuna sp. can also be used as feed for domestic animals.

It was evident from the present study that the legumes which had efficient nodulation with native rhizobia, were also, efficient in biomass production and nitrogen yield. Particularly those legumes which have more nodule biomass contributed significant quantities of nitrogen by biological fixation. In many legumes, nodule biomass is better correlated with biologicat nitrogen fixation than the nodule number (Pate, 1977). Nodulation is influenced by a number of factors including host, soil, 
presence of native rhizobia and environment and their interaction. The legumes which are not nodulated effectively by the native rhizobia require inoculation with suitable rhizobial cultures to reduce their dependence on soil nitrogen pool.

The present study revealed increase in the concentration of major nutrients viz. $\mathrm{N}, \mathrm{P}$ and $\mathrm{K}$ clue to the incorporation of green manures in coconut basins. The potential of creeping cover legumes to increase nutrient levels of plantation soils has already been reported (Pushparajah, 1984). A study on four cover management systems under rubber plantations in Malaysia by Broughton (1977) revealed greater nutrient returns by leguminous crops such as Pueraria Calopogonium and Centrosema when compared to the other management systems. Agboola (1974) reported the capability of the green manure legumes to recycle leached plant nutrients by absorbing the nutrients from lower depths and translocating them to the leaves,

Increase in the rate of evolution of $\mathrm{CO}_{2}$ observed in green manured basins is clue to the active decomposition of incorporated crop resiclue and the higher microbial activity. Plant residues serve both as carbon and energy sources for heterotrophic micro-organisms in soil. Proliferation of total microflora comprising of bacteria, fungi and actinomycetes and micro-organisms capable of increasing the availability of nitrogen and phosphorus, such as asymbiotic nitrogen fixers and phosphate solubilisers clue to the incorporation of C. mucunoides, $P$. phaseoloides and M. invisa has already been reported (Thomas, 1987). The carbon mineralisation pattern was similar in soils incorporated with the green matter from the three legumes. The sharp increase in the $\mathrm{CO}_{2}$ evolution observed upto the fourth week of incubation may be attributed to the rapid clecomposition of readily available water soluble constituents. The rate of mineralisation of plant residues was very rapid and most of the mineralisation occurred before the eighth week of incubation. The present study revealed the suitability of $P$. phaseoloides, $C$. mucunoides and $M$. invisa for the basin management of coconut in laterite soils and they contributed much higher quantities of biomass and nitrogen than that was reported in sandy soils. The cultivation and incorporation of these legumes brought about improvernent in soil fertility parameters to the benefit of plant growth. The basin management with green manure legumes is a simple and less expensive agrotechnique which can be adopted even by small farmers for sustainable agriculture. 


\section{REFERENCES}

AGBOOLA, A.A. 1974. Organic materials as Fertilizers. FAO Bull. 27, Rome, Italy, pp. 147-152.

BRAY, R.H. and KURTZ, L.T. 1945. Determination of total organic and available forms of phosphorus in soils. Soil Sci. $59: 39-45$.

BREMNER, J.M. 1965. Determination of nitrogen in soil by Kjeldahl method. J.- gric. Sci. 55 : 11-13.

BROUGHTON, W.J. 1977. Effect of various cover crops on soil fertility under Hevea brasiliensis Muell. Agg. and on growth of the tree. Agro. Ecosystems. 3 (2) : 147-170.

CABATO, F.H. 1970. Cover cropping in coconut plantations. In Coconut production. ed. R.G. Emata, UCAP, Manila p. 92-97.

PATE, J.S. 1977. Functional biology of dinitrogen fixation by legumes. In. A Treatise on Dinitrogen Fixation. Section III Biology. Hardy, R.W.F. and Silver, W.S. (eds.). John Wiley \& Sons, New York. pp. 473-517.

PRAMER, D. and SCHMIDT, E.L. 1964. Experimental soil micro-biology. Burgess publishing Co., Minneapolis, Minnesota.

PUSHPARAJAH, E. 1982. Non-symbiotic nitrogen fixation and organic matter in the tropics. Proc. $12^{\text {th }}$ Intern. Congr. Soil Sci., New Delhi, India, 8-16 Feb. 1982, pp. 189-197.

REDSHAW, M.J. 1982. Leguminous cover crops, the key to sustained agriculture on upland soils in Indonesia. Indonesian Agric. Res. Dev. J. 4 (1) : 117-123.

STANFORD. G. and ENGLISH, L. 1949. Use of the Flame photometer in rapid soil tests for potassium and calcium. Agronomy J. 41 : 446-447.

THOMAS, G.V. and SHANTARAM, M.V. 1984. In situ cultivation and incorporation of green manure legumes in coconut basins; an approach to improve soil fertility and micobial activity. Plant and Soil. $80: 373-380$.

THOMAS, G.V. 1987. Microbial population, enzyme activity and VA-mycorrhiza in the root region of coconut in relation to in situ green manuring. pp. 267-274. In Proc. PLACROSYMNI, Indian Society for Plantation Crops, CPCRI, Kasaragod. 
Table 1: Growth and modulation of green manure legume in coconut basin in a laterite soil type

\begin{tabular}{|l|c|c|c|c|}
\hline \multirow{2}{*}{ Legume species } & \multicolumn{2}{|c|}{ Biomass and $\mathrm{N}_{2}$ yield } & \multicolumn{2}{c|}{ Nodulation } \\
\cline { 2 - 5 } & $\begin{array}{c}\text { Wet biomass } \\
\text { Kg basin- }{ }^{1}\end{array}$ & $\begin{array}{c}\text { Nitrogen } \\
\text { G basin- }{ }^{1}\end{array}$ & $\begin{array}{c}\text { Nodule by } \\
\text { Wet per 5 plants }\end{array}$ & $\begin{array}{c}\text { Nodule No. } \\
\text { Per 5 plants }\end{array}$ \\
\hline Calopogonium muconoides & $27.21 \pm 5.52 *$ & $186.53 \pm 29.02 *$ & $177.83 \pm 29.16 *$ & $0.413 \pm 0.10 *$ \\
Macrotuloma axillaire & $3.98 \pm 0.58$ & $29.54 \pm 4.28$ & $51.33 \pm 4.70$ & $0.138 \pm 0.02$ \\
Mimosa invisa & $24.97 \pm 2.25$ & $187.55 \pm 17.82$ & $225.50 \pm 39.70$ & $2.372 \pm 0.42$ \\
Macroptilium atropurpureum & $15.92 \pm 3.12$ & $116.58 \pm 22.82$ & $49.50 \pm 10.25$ & $0.288 \pm 0.06$ \\
Pueraria phaseoloides & $28.45 \pm 6.25$ & $196.19 \pm 38.40$ & $238.33 \pm 14.16$ & $1.720 \pm 0.34$ \\
Centrosema pubsescens & $4.96 \pm 1.24$ & $40.25 \pm 10.30$ & $22.67 \pm 5.50$ & $0.108 \pm 0.03$ \\
Mucuna bracteata & $21.06 \pm 3.47$ & $140.07 \pm 23.06$ & $59.33 \pm 10.35$ & $0.330 \pm 0.06$ \\
Crotalaria juncea & $17.57 \pm 1.96$ & $108.48 \pm 12.09$ & $117.67 \pm 7.96$ & $0.403 \pm 0.02$ \\
Leucaena leucocephala & $0.74 \pm 0.02$ & $7.27 \pm 0.30$ & $45.00 \pm 10.00$ & $0.278 \pm 0.08$ \\
Sesbania aegiptica & $1.85 \pm 0.11$ & $10.51 \pm 3.11$ & $219.00 \pm 31.5$ & $0.538 \pm 0.14$ \\
\hline
\end{tabular}

* Standard error of the mean. 


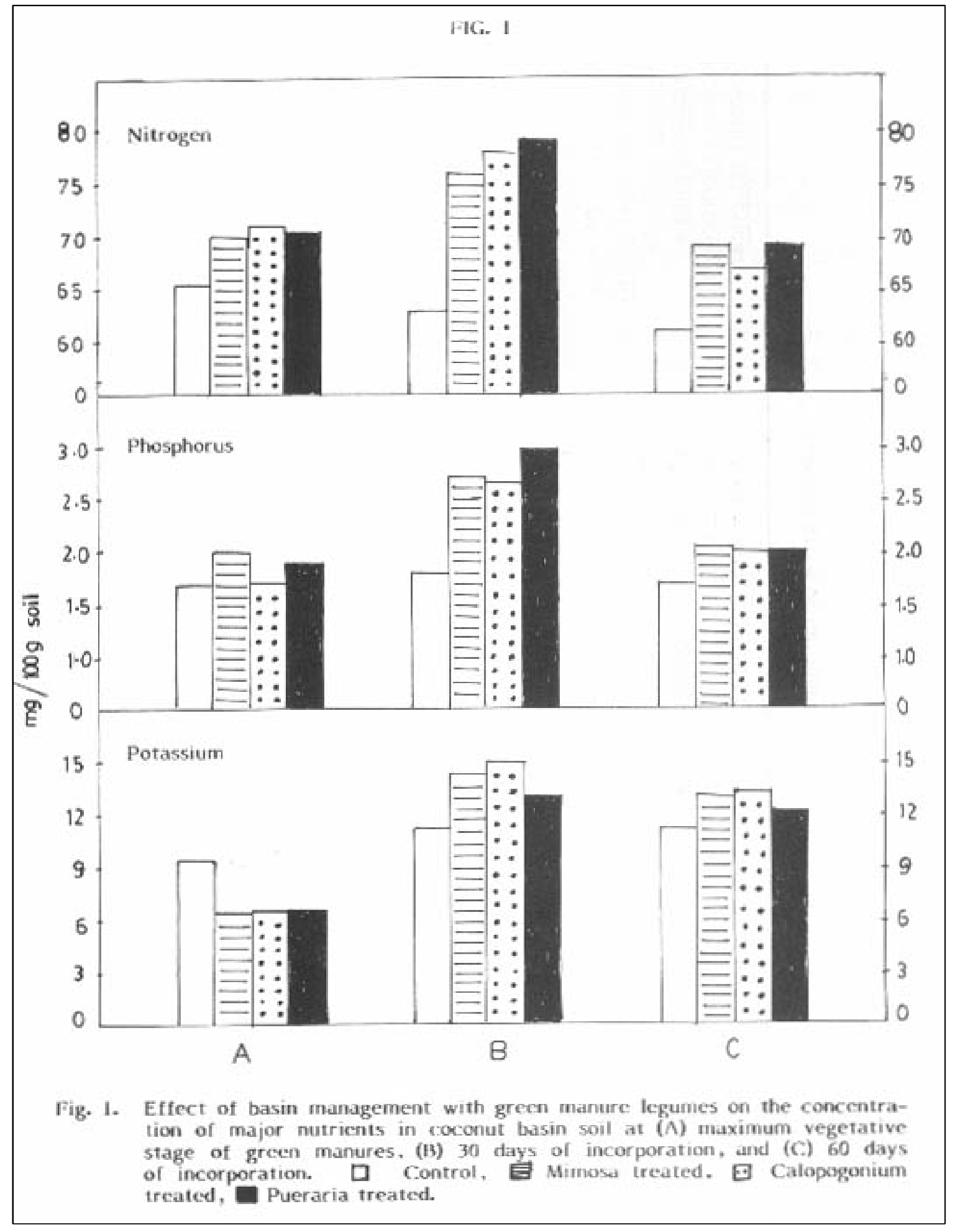




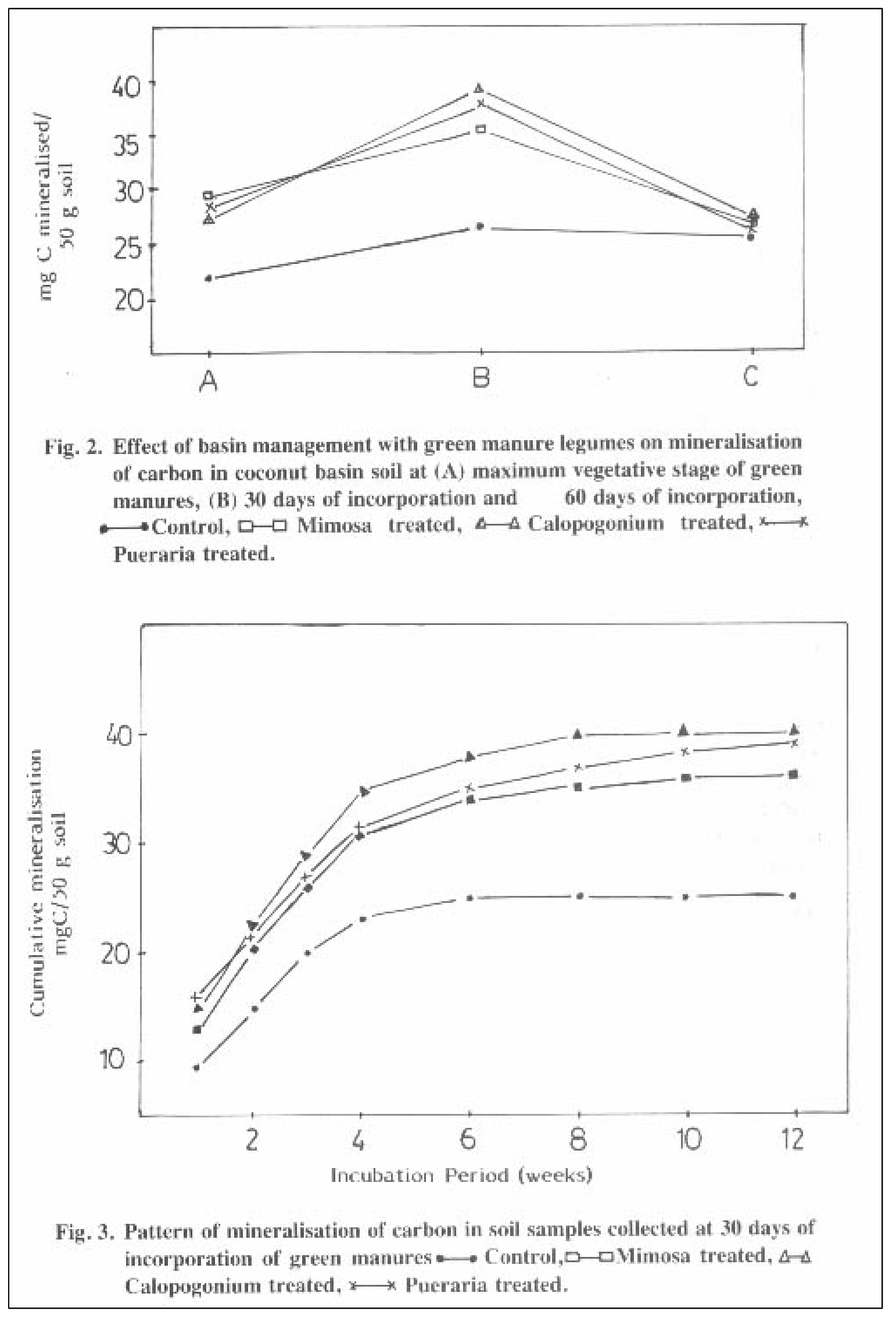

